\title{
Removal of Lead from Drinking Water by Bioadsorption Technique: An Eco-friendly Approach
}

\author{
Prasenjit Mondal $\uparrow$, B. P. Yadav and N. A. Siddiqui \\ University of Petroleum and Energy Studies, Dehradun, U.K., India \\ $†$ Corresponding author: Prasenjit Mondal; pmondal@ddn.upes.ac.in
}

Nat. Env. \& Poll. Tech.

Website: www.neptjournal.com

Received: 09-12-2019

Revised: 06-01-2020

Accepted: 01-02-2020

Key Words:

Heavy Metal Concentration

Orange peels

Bio-adsorption

Bio-adsorbent

\begin{abstract}
India is the world's largest user of groundwater, accounting for 25 per cent of the world's extracted groundwater. Contamination of water bodies is the main problem for degrading the potable water quality in India. The contaminants, mainly cadmium, chromium, nickel, lead, zinc, copper, calcium, fluoride, nitrates, etc. have a significant impact on waters. There have been several advancements in technology for removal or reduction of these contaminants in water such as reverse osmosis, UV filtration, distillation and ion exchange. But these methods are not found to be eco-friendly and costeffective. This paper elaborates various techniques of organic nature that can be used to reduce/ remove the heavy metals from water bodies using orange peels as a bioadsorbent and detailed experimentation for the removal of lead ion concentration from water. In the present study, synthetic water with various heavy metals of known concentration was treated by a bioadsorbent (orange peels) by changing various parameters such as adsorbent particle size, dose, initial $\mathrm{pH}$, etc. At pH 7, dose 0.5 $\mathrm{g}$, and adsorbent particle size of $250 \mu \mathrm{m}$, a drastic reduction in the concentration of lead from $10 \mathrm{ppm}$ to $0.213 \mathrm{ppm}$ in $50 \mathrm{~mL}$ synthetic sample was observed.
\end{abstract}

\section{INTRODUCTION}

Water stands first among the important fundamental requirements and also a basic nutrient having critical importance to human life (Howard et al. 2003) and is involved in almost every bodily function from digestion to excretion (Feldman et al. 1996). Water is transparent, colourless, odourless, and tasteless and covers almost $71 \%$ per cent of the earth's surface (Lindstrom 2012, Khyade \& Swaminathan 2016). Coming to drinking water, it plays an important role in the life of every living organism (Vitousek et al. 1997). It boosts the metabolism and helps in breaking down the food but not all people get the quality drinking water (Congress 1995).

The problem we are facing currently is the pollution of water through various sources. Urbanization and industrialization are the main reasons for the pollution of water (Shiklomanov 1991, Czech et al. 2000, Le et al. 2010). With the increase in industrialization, there has been an increase in the high usage of different metals, chemicals and materials, etc. for the production of various products which resulted in producing waste which is being released into nearby water resources (Shukla et al. 2002). The chemicals, when mixed with water which is the source for drinking water in many areas, makes it toxic. Most of the people in many households are drinking the water which contains pathogens that may cause various diseases like typhoid, jaundice, diarrhoea, etc.
(Niemczynowicz 1999). A filtering mechanism uses techniques like RO, activated carbon filters to filter the water to make it fit for drinking (Matilainen et al. 2010).

The present work mainly focused on the removal of lead ions from water, a persisting problem in India, by using organic methods such as orange peels.

\section{Heavy Metal Pollution in Water}

Heavy metals have higher atomic weights and are approximately five times heavier than water. Many ecological and global public health concerns with the contamination by these metals have been emerged in recent years (Demirbas 2005). Heavy metals extensive use in several industrial, agricultural, domestic and technological applications has increased their exposure to the environment (Mulligan et al. 2001).

Pollution resulting from land runoff, precipitation, atmospheric deposition or land drainage is known as non-point source pollution (World Water Development Report 2017). Non-point sources are not easy to identify like the use of excess fertilizers or pesticides from agricultural lands or toxic chemicals from urban run-off and thus heavy metals find their way into water by industrial, agricultural, pharmaceutical, domestic effluents and atmospheric sources (Tarver 2008).

Heavy metals are naturally occurring in the earth's crust but the pollution caused by them is mainly due to the an- 
thropogenic sources like mining, industrial production and using compounds containing metals (Annadurai et al. 2003). Some of the industrial sources include metal processing in refineries, coal burning in power plants, textiles, microelectronics, nuclear power stations and high tension lines, and combustion of petroleum (Hegazi 2013).

The metals like $\mathrm{Co}, \mathrm{Cu}, \mathrm{Cr}, \mathrm{Fe}, \mathrm{Mg}, \mathrm{Mn}, \mathrm{Mo}, \mathrm{Ni}, \mathrm{Se}$ and $\mathrm{Zn}$ are essential nutrients to the human body in adequate amounts. Insufficiency of these micronutrients in the human body results in a variety of ailments (Dobaradaran et al. 2017). Heavy metals are classified as human carcinogens (known or probable) according to the U.S. Environmental Protection Agency, and the International Agency for Research on Cancer (Howard et al. 2003). They are systemic toxicants which can induce multiple organ damage, even at lower levels of exposure (Pehlivan et al. 2008).

Heavy metals pollute the groundwater bodies and the surface water bodies like rivers, lakes, ponds. The primary metals like lead, arsenic, copper, cadmium, mercury and nickel are also known as trace elements, which are normally found in low concentrations. Surface water contamination is due to mining, dumping of solid wastes containing metal salts and discharge of effluents from battery and paint manufacturing, electroplating, viscous-rayon manufacturing, copper picking industries (Tokalioğlu et al. 2000).

\section{Previous Works on Heavy Metal Removal Techniques}

The rapid growth in industries over the start of the 20th century has increased the demand for freshwater and thereby discharging the wastewater into the nearby water sources (Barlow \& Clarke 2017). The discharged effluents from the industries contain harmful heavy metals like lead, chromium, cadmium, etc. in the form of dyes, coatings, pigments and so on and many of them are considered as hazardous to health because of their toxicity to human health. There are many methods available for the removal of these heavy metals from water such as reverse osmosis, chemical oxidation, adsorption, membrane separation, ion exchange, etc., out of which adsorption is considered as the simple and efficient method because of its ease of operation and versatility. The summative assessment on the removal of heavy metals from water by adsorption technique using organic wastes as adsorbents is listed in Table 1.

\section{MATERIALS AND METHODS}

\section{Preparation of Adsorbent}

Orange peels were used as adsorbents for the removal of

Table 1: Summative assessment on the removal of heavy metals from water using organic waste as adsorbent.

\begin{tabular}{|c|c|c|c|c|}
\hline S. No. & Objective & Brief Summary & Outcome & References \\
\hline 1 & $\begin{array}{l}\text { Water purifica- } \\
\text { tion using differ- } \\
\text { ent waste fruit } \\
\text { cortexes for the } \\
\text { removal of heavy } \\
\text { metals. }\end{array}$ & $\begin{array}{l}\text { Water can be purified by using different fruit cortices } \\
\text { to remove heavy metals. They used the peels of fruits } \\
\text { like kiwi, tangerine and banana and crushed them into } \\
\text { powder to an optimum size of } 1 \mathrm{~mm} \text { and } 2 \mathrm{~mm} \text {. A water } \\
\text { sample was made by taking } 50 \mathrm{~mL} \text { wastewater and } 0.5 \mathrm{~g} \\
\text { of the crushed powder of particle size both } 1 \mathrm{~mm} \text { and } 2 \\
\text { mm is added into the flask as adsorbent. It is then kept in } \\
\text { a shaker at } 158 \mathrm{rpm} \text { for } 60 \text { minutes. It was later filtered } \\
\text { and then the concentration of the metals was analysed } \\
\text { by Inductively Coupled Plasma (ICP) }\end{array}$ & $\begin{array}{l}\text { It has shown that the particles of size } 1 \mathrm{~mm} \\
\text { had better adsorption when compared to the } \\
\text { particles of size } 2 \mathrm{~mm} \text {. Of the fruits used, } \\
\text { kiwi fruit gave better adsorption results than } \\
\text { banana. The order of adsorption capacity } \\
\text { of the metal ions for banana was } \mathrm{Cr}<\mathrm{Cd} \\
<\mathrm{Zn} \text { and for Kiwi and tangerine, it was } \mathrm{Cd} \\
<\mathrm{Cr}<\mathrm{Zn} \text {. The capacity of adsorption will } \\
\text { depend upon the pH, adsorbent dosage } \\
\text { and the contact time. After conducting the } \\
\text { experiments, the optimum value of pH was } \\
\text { found to be } 6.0\end{array}$ & $\begin{array}{l}\text { (Al-Qahtani } \\
2016)\end{array}$ \\
\hline 2 & $\begin{array}{l}\text { Adsorption of } \\
\text { heavy metals } \\
\text { from water us- } \\
\text { ing banana and } \\
\text { orange peels. }\end{array}$ & $\begin{array}{l}\text { banana peels and orange peels for the removal of heavy } \\
\text { metals like } \mathrm{Cu}^{2+}, \mathrm{Zn}^{2+}, \mathrm{Co}^{2+}, \mathrm{Ni}^{2+} \text { and } \mathrm{Pb}^{2+} . \text { Banana and } \\
\text { orange peels, both were cleaned with double distilled } \\
\text { water, dried and crushed into powder with particle size } \\
\text { of } 1-5 \mathrm{~mm} \text {. The peels are treated with } 0.4 \text { mol/L Sodium } \\
\mathrm{Hydroxide}, 0.4 \mathrm{~mol} / \mathrm{L} \text { Nitric Acid \& distilled water. } \\
15 \mathrm{~g} \text { of banana peels and orange peels were soaked } \\
\text { in } 0.4 \mathrm{~mol}^{\mathrm{L}} \mathrm{L} \mathrm{HNO}_{3} \text { for } 24 \text { hours. "Synthetic solutions } \\
\text { of CuSO}, \mathrm{CoSO}_{4}, \mathrm{NiSO}_{4}, \mathrm{ZnSO}_{4} \text { and } \mathrm{Pb}\left(\mathrm{NO}_{3}\right)_{2} \text { are } \\
\text { prepared". Experiments are done by adding } 0.1 \text { gms of } \\
\text { adsorbent in the } 100 \mathrm{~mL} \text { metal solution at a speed of } \\
180 \mathrm{rpm} \text { for } 24 \text { hours and centrifugation at } 10,000 \mathrm{rpm} \\
\text { for } 20 \text { minutes, then later the concentration of metals } \\
\text { were analysed by an atomic absorbance spectropho- } \\
\text { tometer (Varian Model 202FS) }\end{array}$ & $\begin{array}{l}\text { The results from the experiments have } \\
\text { shown that the maximum adsorption was } \\
\text { at around } \mathrm{pH} \text { 6- } 8 \text { for banana and orange } \\
\text { peels and the adsorption decreased with the } \\
\text { increase in } \mathrm{pH} \text {. The adsorption capacity was } \\
\text { found to be } 7.97 \mathrm{mg} / \mathrm{g} \text { for lead, } 6.88 \mathrm{mg} / \mathrm{g} \\
\text { for nickel, } 5.80 \mathrm{mg} / \mathrm{g} \text { for zinc, } 4.75 \mathrm{mg} / \mathrm{g} \\
\text { for copper, and } 2.55 \mathrm{mg} / \mathrm{g} \text { for cobalt using } \\
\text { banana peels. And for orange peels it was } \\
7.75 \mathrm{mg} / \mathrm{g} \text { for lead, } 6.01 \mathrm{mg} / \mathrm{g} \text { for nickel, } \\
5.25 \mathrm{mg} / \mathrm{g} \text { for zinc, } 3.65 \mathrm{mg} / \mathrm{g} \text { for copper } \\
\text { and } 1.82 \mathrm{mg} / \mathrm{g} \text { for cobalt. The experiment } \\
\text { also shown that maximum adsorption was } \\
\text { attained at high pH with max level of lead } \\
\text { by using banana peels was } 7.97 \mathrm{mg} / \mathrm{g} \text { and by } \\
\text { using orange peels it was } 7.75 \mathrm{mg} / \mathrm{g} \text {. }\end{array}$ & $\begin{array}{l}\text { (Annadurai, } \\
\text { Juang et al. } \\
2003 \text { ) }\end{array}$ \\
\hline
\end{tabular}


Cont Table...

\begin{tabular}{|c|c|c|c|c|}
\hline S. No. & Objective & Brief Summary & Outcome & References \\
\hline 3 & $\begin{array}{l}\text { Removal of } \\
\text { heavy metals } \\
\text { from wastewater } \\
\text { using agricultur- } \\
\text { al and industrial } \\
\text { wastes as adsor- } \\
\text { bents. }\end{array}$ & $\begin{array}{l}\text { Synthetic wastewater with known concentrations of } \\
\text { copper sulphate, nickel nitrate and iron sulphate metal } \\
\text { solutions are made separately in double distilled water } \\
\text { using } \mathrm{Cu}, \mathrm{Ni}, \mathrm{Fe} \text {. The stock solution consisting of } \\
20 \mathrm{mg} / \mathrm{L} \text { as the adsorbent dose and concentration of } \\
\text { metal }(\mathrm{Cu}, \mathrm{Ni}, \mathrm{Fe}) \text { is around } 10 \mathrm{mg} / \mathrm{L} \text {. The agitation } \\
\text { speed is } 200 \mathrm{rpm} \text {. The adsorbent doses of } 20,30,40,50 \\
\text { and } 60 \mathrm{mg} / \mathrm{L} \text { are taken. The adsorbents and the metal } \\
\text { ions are added and stabilized by agitating to attain } \mathrm{pH} \\
\text { of range } 2-10\end{array}$ & $\begin{array}{l}\text { water is purified by removing heavy metals } \\
\text { using agricultural wastes like rice husk and } \\
\text { industrial wastes like fly ash. First, The } \\
\text { experiments are done and the results shown } \\
\text { were that the agricultural waste rice husk } \\
\text { found to be efficient in removing the metals } \\
\text { like Fe, Pb and Ni whereas the industrial } \\
\text { waste, fly ash has shown to be effective in } \\
\text { removing i.e. adsorbing Cu and Cd. The } \\
\text { experiments were also done by increasing } \\
\text { the adsorbent concentration of rice husk } \\
\text { and it was found that the Fe removal by } \\
\text { using rice husk increased from } 68.59 \% \text { to } \\
99.25 \% \text {. Same when done for Pb, it was } \\
\text { increased from } 22.22 \% \text { to } 87.17 \% \text {. When } \\
\text { the concentration of fly ash was increased, } \\
\text { the Cd removal increased from } 25.21 \% \text { to } \\
73.5 \% \text {. Same when done for Cu, the removal } \\
\text { increased from } 37.38 \% \text { to } 98.54 \% \text {. The ad- } \\
\text { sorption capacity was dependent on the level } \\
\text { of pH, dosage of the adsorbent and the time } \\
\text { of contact with the respective adsorbent. The } \\
\text { contact time for attaining the desired level } \\
\text { of metal ions was found to be } 2 \mathrm{~h} \text { and pH } \\
\text { range was } 6-7 \text { for the effective adsorption. }\end{array}$ & $\begin{array}{l}\text { (Hegazi } \\
\text { 2013) }\end{array}$ \\
\hline 4 & $\begin{array}{l}\text { A laboratory } \\
\text { study using ma- } \\
\text { ple leaves as a } \\
\text { bio-sorbent for } \\
\text { lead removal } \\
\text { from aqueous } \\
\text { solutions. }\end{array}$ & $\begin{array}{l}\text { Lead was removed from aqueous by using maple leaves } \\
\text { as a bio-sorbent. The materials used were one kg of ma- } \\
\text { ple leaves, salt, lead nitrate solution, } \mathrm{Pb} \text { (II) and water. }\end{array}$ & $\begin{array}{l}10 \mathrm{mg} / \mathrm{L} \text { removed } 98.2 \% \mathrm{~Pb} \text { (II) ions than } \\
\text { other concentrations and } 0.5 \mathrm{~g} \text { Maple leaves } \\
\text { posed higher removal for } \mathrm{Pb} \text { (II) ions. A } \\
\text { sharp increase in bio-sorption occurred } \\
\text { in the } \mathrm{pH} \text { range } 2.5-4.5 \text {. The maximum } \\
\text { bio-sorption was } 98.5 \% \text { for } \mathrm{Pb} \text { (II) ions at } \\
\mathrm{pH} \text { 6.3. Smaller particles }(<75 \mu \mathrm{m}) \text { have } \\
\text { greater } \mathrm{Pb} \text { (II) removal capacity. }\end{array}$ & $\begin{array}{l}\text { (Hossain et } \\
\text { al. 2014) }\end{array}$ \\
\hline 5 & $\begin{array}{l}\text { Self-purification } \\
\text { of the marine } \\
\text { environment } \\
\text { for heavy met- } \\
\text { als: A study on } \\
\text { removal of lead } \\
\text { and copper by } \\
\text { cuttlebone. }\end{array}$ & $\begin{array}{l}\text { Self-purification marine environment done by the cut- } \\
\text { tlefish to remove lead and copper. In this experiment, } \\
\text { cuttlebone from cuttle fish was collected and washed } \\
\text { with tap and deionized water and dried at } 105^{\circ} \mathrm{C} \text { for } \\
24 \mathrm{hrs} \text { and grinded to particles with sizes between } 0.3- \\
0.7 \mathrm{~mm} \text {. The solutions of lead and copper are prepared } \\
\text { by dissolving the required amount of lead nitrate and } \\
\text { copper nitrate Pent hydrate in de-ionized water. The pH } \\
\text { values were modified and calibrated by using } 0.1-1.0 \mathrm{M} \\
\mathrm{HCl} \text { and } 0.1-1.0 \mathrm{M} \mathrm{NaOH} \text {. Experiment was conducted } \\
\text { in batch reactor on shaker at } 120 \mathrm{rpm} \text { at room temper- } \\
\text { ature. The pH is maintained at } 5 \text { initially. Experiments } \\
\text { were done with metal concentrations of } 10,20 \text {, and } \\
50 \mathrm{mg} / \mathrm{L} \text { and the adsorbent dose of } 0.1 \text { to } 1.0 \mathrm{~g} / \mathrm{L} \text { with } \\
\text { constant ion concentration of } 50 \mathrm{mg} / \mathrm{L} \text { initially. The } \\
\text { adsorption was studied by keeping the range of pH } \\
\text { between } 2-7 \text {. Later, the concentration of metals was } \\
\text { analysed by using AAS. }\end{array}$ & $\begin{array}{l}\text { The results were that the capacity of cuttle- } \\
\text { bone to adsorb } \mathrm{Pb} \text { and } \mathrm{Cu} \text { were found to be } \\
45.9 \mathrm{mg} / \mathrm{g} \text { and } 39.9 \mathrm{mg} / \mathrm{g} \text {. The adsorption of } \\
\mathrm{Pb} \text { and } \mathrm{Cu} \text { increased with an increase in } \mathrm{pH} \\
\text { and the max adsorption occurred when the } \\
\mathrm{pH} \text { was } 7.0 \mathrm{and} \text { the adsorption was found } \\
\text { to be } 18.7 \mathrm{mg} / \mathrm{g} \text { and } 19.8 \mathrm{mg} / \mathrm{g} \text { for } \mathrm{Pb} \text { and } \\
\mathrm{Cu} \text {. And the maximum uptakes were found } \\
\text { when at the } \mathrm{pH} \text { values } 5.0 \text { and } 5.5 \text {. }\end{array}$ & $\begin{array}{l}\text { (Dobara- } \\
\text { daran, } \\
\text { Nabipour et } \\
\text { al. 2017) }\end{array}$ \\
\hline
\end{tabular}


Cont Table...

\begin{tabular}{|c|c|c|c|c|}
\hline S. No. & Objective & Brief Summary & Outcome & References \\
\hline 6 & $\begin{array}{l}\text { Adsorptive re- } \\
\text { moval of Arse- } \\
\text { nic from aqueous } \\
\text { solution by waste } \\
\text { litchi pericarps. }\end{array}$ & $\begin{array}{l}\text { Litchi pericarps are washed with tap water and ultrapure } \\
\text { water. They are dried at } 70^{\circ} \mathrm{C} \text { and then sized through } \\
\text { a } 60 \text { mesh and stored in a polyethylene bottle. A stock } \\
\text { solution of sodium arsenate } \mathrm{NaAsO}_{2}(1,000 \mathrm{mg} / \mathrm{L}) \\
\text { was prepared with ultrapure water. Polyethylene tubes } \\
\text { of } 100 \mathrm{~mL} \text { are taken with } 50 \mathrm{~mL} \text { of aqueous arsenic } \\
\text { solution. Different adsorption capacities are observed } \\
\text { with } \mathrm{LPs}(1-20 \mathrm{~g} / \mathrm{L}) \text { with varying initial arsenate con- } \\
\text { centration }(0.01-100 \mathrm{mg} / \mathrm{L}) \text { at } 293.15 \mathrm{~K} \text {. The } \mathrm{pH} \text { is } \\
\text { maintained between } 2-11 \text { by using } 0.1 \mathrm{M} \mathrm{HCl} \text { and } 0.1 \\
\mathrm{M} \mathrm{NaOH} \text { solutions. } \\
\text { The polyethylene centrifuge tubes were shaken in a } \\
\text { vertical temperature oscillation incubator at } 220 \mathrm{rpm} \\
\text { for } 5 \text { to } 180 \text { min. These suspensions are filtered through } \\
0.45 \mu \mathrm{m} \text { "cellulose acetate membrane filters". Arsenic } \\
\text { filtrates are observed through AAS. }\end{array}$ & $\begin{array}{l}\text { The removal rate increases from } 24.0 \% \text { to } \\
97.74 \% \text { as the adsorbent dose increases } \\
\text { from } 1.0 \text { to } 10.0 \mathrm{~g} / \mathrm{L} \text {. No further increase in } \\
\text { the removal rate of As (III) is observed for } \\
\mathrm{LP} \text { additions from } 10.0 \text { to } 20.0 \mathrm{~g} / \mathrm{L} \text {. Arsenic } \\
\text { removal efficiency increases from } 88 \% \text { to } \\
93 \% \text { as the contact time increases from } \\
10 \text { to } 60 \text { min. The percentage removal rate } \\
\text { increases by an increase in pH from } 2 \text { to } 5 \text {, } \\
\text { and then it decreases slightly with a further } \\
\text { pH increase from 6-7. }\end{array}$ & $\begin{array}{l}\text { (Li, Qi et al. } \\
2016)\end{array}$ \\
\hline 7 & $\begin{array}{l}\text { "Arsenic remov- } \\
\text { al from aqueous } \\
\text { solutions by ad- } \\
\text { sorption on red } \\
\text { mud". }\end{array}$ & $\begin{array}{l}\text { Arsenic is removed from water by using red mud as an } \\
\text { adsorbent. In this paper it is mentioned that mud was } \\
\text { wet sieved through a } 200 \text { mesh screen and was washed } \\
\text { for five times with distilled water. The suspension was } \\
\text { filtered and was dried at } 105^{\circ} \mathrm{C} \text {, ground and sieved } \\
\text { through a } 200 \text { mesh screen. Stock solutions of } 1 \mathrm{As} \text { (III) } \\
\text { were prepared by adding } 1.320 \mathrm{~g} \text { of } \mathrm{As}_{2} \mathrm{O}_{3} \text { in } 10 \mathrm{~mL} \text { of } \\
5 \mathrm{M} \mathrm{NaOH} \text { and made it up to } 1 \mathrm{~L} \text { with distilled water. } \\
\text { Another stock solution of } 1 \mathrm{~g} / \mathrm{L} \mathrm{As}(\mathrm{V}) \text { was prepared by } \\
\text { adding } \mathrm{Na}_{2} \mathrm{HSO} \mathrm{H}_{4} \cdot 7 \mathrm{H}_{2} \mathrm{O} \text {. Solutions with } 125 \text { to } 1500 \mathrm{mg} \\
\text { of arsenic and } 5 \mathrm{~mL} \text { of } 0.1 \mathrm{M} \mathrm{NaCl} \text { were made to } 50 \\
\text { mL using distilled water. The red mud was added as an } \\
\text { adsorbent into the solution and shaken at the rate of } 800 \\
\text { cycles/min with a mechanical shaker. Later, the mixture } \\
\text { was centrifuged at } 10000 \mathrm{rpm} \text { for } 10 \text { mins }\end{array}$ & $\begin{array}{l}\text { As }(\mathrm{III}) \text { and } \mathrm{As}(\mathrm{V}) \text { adsorptions are obtained } \\
\text { within } 45 \text { and } 90 \text { min respectively at } 25^{\circ} \mathrm{C} \text {, } \\
133.5 \mu \mathrm{mol} / \mathrm{L} \text { concentration and } 20 \mathrm{~g} / \mathrm{L} \text { red } \\
\text { mud dosage. As(III) and As(V) adsorptions } \\
\text { take places at } \mathrm{pH} 9.5 \text { and } 3.2 \text {. The adsorption } \\
\text { densities at these conditions are } 4.31 \text { and } \\
5.07 \mu \mathrm{mol} / \mathrm{g} \text { for As(III) and As(V). }\end{array}$ & $\begin{array}{l}\text { (Altundo an } \\
\text { et al. 2000) }\end{array}$ \\
\hline 8 & $\begin{array}{l}\text { Removal of } \\
\mathrm{Pb}(\mathrm{II}) \text { and } \mathrm{Cd}(\mathrm{II}) \\
\text { from water by } \\
\text { adsorption on } \\
\text { peels of banana. }\end{array}$ & $\begin{array}{l}\text { Banana peels were dried in sunlight for } 5 \text { days and in an } \\
\text { oven at } 70^{\circ} \mathrm{C} \text {. The dried peels were sieved through } 60 \\
\text { mesh screen. Standard solutions with desired concen- } \\
\text { trations }(10-100 \mu \mathrm{gm} / \mathrm{L}) \text { of lead nitrate and cadmium } \\
\text { nitrate were prepared. Six solutions with concentrations } \\
\text { of } 30,40,50,60,70 \text { and } 80 \mu \mathrm{gm} / \mathrm{L} \text { of lead and cadmium } \\
\text { were made with pH adjusted to } 5 \text { for lead and } 3 \text { for } \\
\text { cadmium. Then adsorbent of } 2.0 \mathrm{~g} \text { for lead and } 1.5 \mathrm{~g} \\
\text { for cadmium were added } 50 \mathrm{~mL} \text { of each solution which } \\
\text { was agitated for half an hour. Later the concentration } \\
\text { of the metals was analysed by AAS. }\end{array}$ & $\begin{array}{l}\text { From the results, it was observed that banana } \\
\text { peels were effective in removing cadmium } \\
\text { compared to lead. } 1 \mathrm{~g} \text { of banana peels ad- } \\
\text { sorbed } 5.71 \mathrm{~g} \text { of cadmium and } 2.18 \mathrm{~g} \text { of lead. } \\
\text { Max adsorption of cadmium was observed } \\
\text { at } \mathrm{pH} 3 \text { and for the lead at } \mathrm{pH} 5 \text {. }\end{array}$ & $\begin{array}{l}\text { (Anwar et al. } \\
2010 \text { ) }\end{array}$ \\
\hline
\end{tabular}

lead from water. Orange peels were collected from the juice shops in Dehradun, India. They were washed with water for removal of any dirt and dried in a hot air oven for $4 \mathrm{~h}$ at $80^{\circ} \mathrm{C}$ and $6 \mathrm{~h}$ at $105^{\circ} \mathrm{C}$ (total of 10 hours). They were cut into pieces using a grinding machine and sieved to various sizes like $250 \mu \mathrm{m}, 500 \mu \mathrm{m}$ and $850 \mu \mathrm{m}$ for the experimentation.

\section{Preparation of Stock Solution}

1000 ppm stock solution was prepared and diluted with distilled water to make standard solutions of $5 \mathrm{ppm}, 10 \mathrm{ppm}$,
$15 \mathrm{ppm}, 20 \mathrm{ppm}$ and $25 \mathrm{ppm}$. The experiment was carried out using $10 \mathrm{ppm}$ and $15 \mathrm{ppm}$ stock solutions and rest were used as standards in atomic absorption spectroscopy.

\section{Equipment and Chemicals Used}

$\mathrm{pH}$ was checked by using a digital $\mathrm{pH}$ meter. The metal solution was taken and the exact selected size and dose of adsorbent was added and stirred using a magnetic stirrer at $600 \mathrm{rpm}$ for $30 \mathrm{~min}$. The metal solution was given 2 -h time for settling and filtered using a Waterman Filter paper of size 
400 micron. The $\mathrm{pH}$ was adjusted to the required value (4, $6,8)$ using $0.1 \mathrm{~N} \mathrm{HCl}$ or $0.1 \mathrm{~N} \mathrm{NaOH}$ solutions.

Size of adsorbent: $250 \mu \mathrm{m}, 500 \mu \mathrm{m}, 850 \mu \mathrm{m}$

Dose: $0.5 \mathrm{~g}, 1 \mathrm{~g}$ and $2 \mathrm{~g}$

\section{Study of Process Parameters}

Effects of various parameters like adsorbent particle size, $\mathrm{pH}$ and dose were studied by keeping agitation speed at $600 \mathrm{rpm}$ for 30 min constant. For studying the effect of one parameter, the other three parameters were kept constant. Standard values of various heavy metals are mentioned in Table 2 .

\section{RESULTS AND DISCUSSION}

It is observed that the removal efficiency increases with increase in $\mathrm{pH}$ and is maximum at $\mathrm{pH} 7$ and started decreasing from $\mathrm{pH}$ 8. The removal efficiency was tested at three different $\mathrm{pH}$ values starting from $\mathrm{pH} 4, \mathrm{pH} 7$ and $\mathrm{pH} 8$. Anwar et al. (2010) mentioned that the $\mathrm{pH}$ of the stock solution is one of the most important factors that decides the extent of adsorption of heavy metal ions. As shown in Fig. 1, adsorp- tion efficiency increases from $\mathrm{pH} 4$ to $\mathrm{pH} 7$ which is acidic and declined after $\mathrm{pH} 7$ which is optimum $\mathrm{pH}$. At lower $\mathrm{pH}$, the hydrogen ions $\left(\mathrm{H}^{+}\right)$compete with heavy metal cations for active adsorption sites. But beyond the optimum $\mathrm{pH}$, the adsorption sites will not be activated and metal cations will react with $\left(\mathrm{OH}^{-}\right)$ions and form metal hydroxide precipitate which makes adsorption uncertain (Anwar et al. 2010).

It was observed that at $0.5 \mathrm{~g}$ as the adsorbent dose $250 \mu$ size and $\mathrm{pH} 7$, the maximum metal removal efficiency was observed, i.e. (97.87\%) (Fig. 2). As the adsorbent size increases, the available surface area for adsorption decreases and its available active sites decrease, thereby decreasing the metal removal efficiency (Fig. 3).

Same experiments were carried out by preparing $15 \mathrm{ppm}$ lead concentration stock solution in $50 \mathrm{~mL}$ distilled water.

It was observed that for $10 \mathrm{ppm}$ metal concentration stock solution at $0.5 \mathrm{~g}$ as adsorbent dose and $250 \mu$ size and $\mathrm{pH}$ 7 , the maximum metal removal efficiency was $97.87 \%$, and for $15 \mathrm{ppm}$ metal concentration at $0.5 \mathrm{~g}$ as adsorbent dose and $250 \mu$ size and $\mathrm{pH} 7$, the maximum metal removal efficiency was $96.57 \%$ (Fig. 4). As the adsorbent size increases,

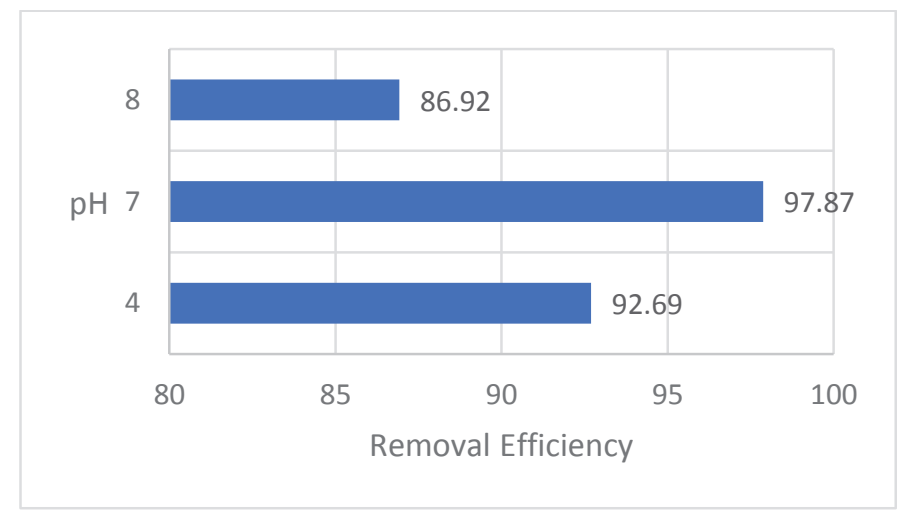

Fig. 1: Removal Efficiency with respect to varying $\mathrm{pH}$ at $10 \mathrm{ppm}$ lead concentration, adsorbent size- $250 \mu \mathrm{m}$ and adsorbent dose- $0.5 \mathrm{~g}$.

Table 2: Drinking water standards: IS 10500:2012.

\begin{tabular}{|llll|}
\hline S. No. & Element & Acceptable Limit $\mu \mathrm{g} / \mathrm{L}(\mathrm{BIS} 10500: 2012)$ & PEL $\mu \mathrm{g} / \mathrm{L}$ (BIS 10500:2012) \\
\hline 1 & Arsenic & 10 & 50 \\
2 & Cadmium & 3 & No relaxation \\
3 & Chromium & 50 & No relaxation \\
4 & Copper & 50 & 1500 \\
5 & Iron & 300 & No relaxation \\
6 & Lead & 10 & No relaxation \\
7 & Mercury & 1 & No relaxation \\
\hline
\end{tabular}




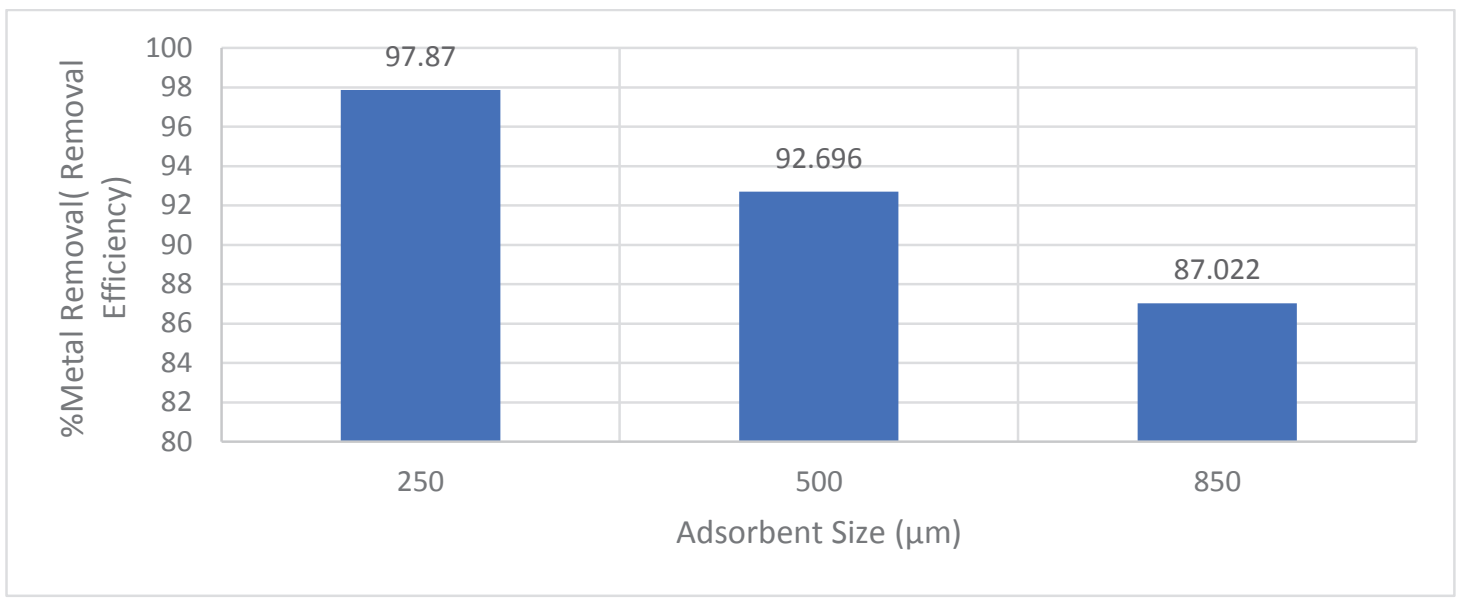

Fig. 2: Effect of adsorbent size for $10 \mathrm{ppm}$ lead concentration at adsorbent dose- $0.5 \mathrm{~g}$ and $\mathrm{pH} 7$.

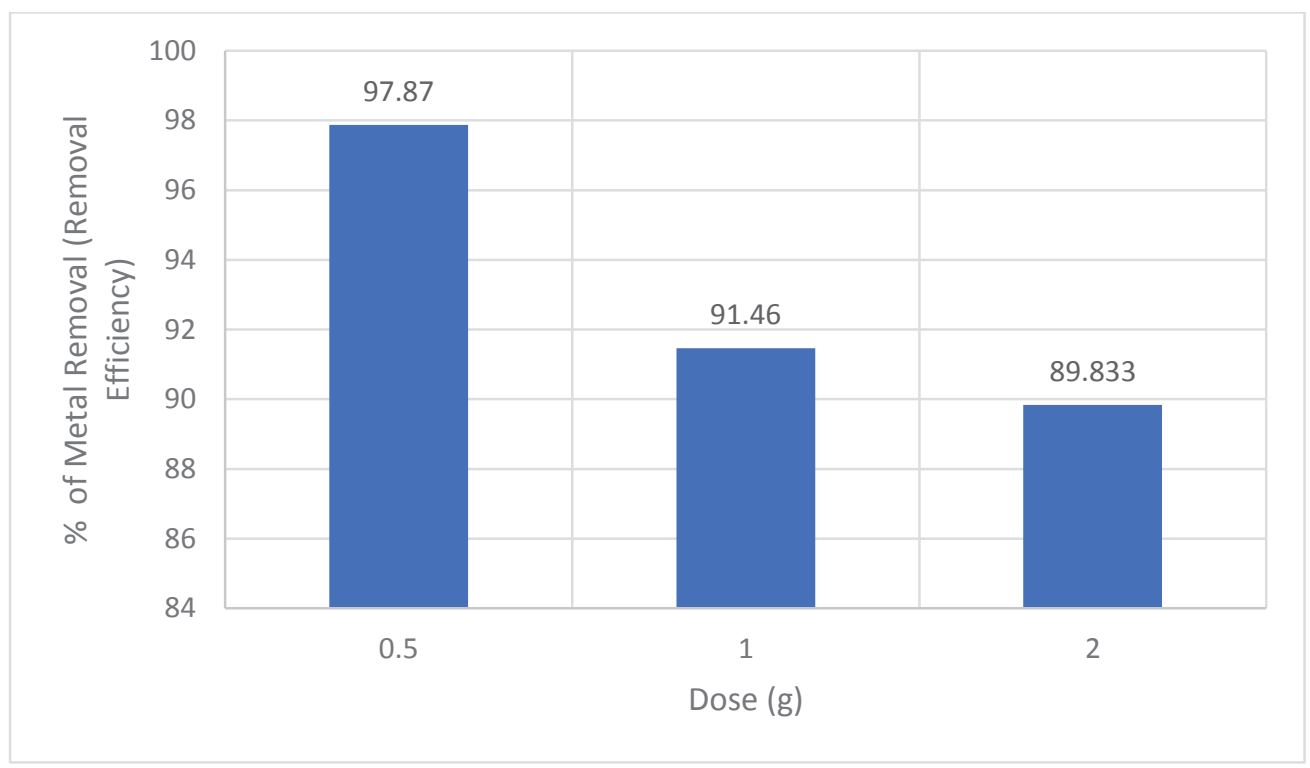

Fig. 3: Effect of adsorbent dose at adsorbent size- $250 \mu$ and $\mathrm{pH}-7$ on metal removal efficiency.

the available surface area for adsorption decreases and its available active sites decrease thereby decreasing the metal removal efficiency (Fig. 5).

\section{CONCLUSIONS}

A total of 20 samples were collected and tested by atomic absorption spectroscopy. The following observations were made.

1. The removal efficiency was found to mainly depend on adsorbent particle size, adsorbent dose and $\mathrm{pH}$.

2. The RPM of the magnetic stirrer was kept constant throughout (600 RPM for 20 mins). Particles having sizes in the range of $250-500 \mu \mathrm{m}$ are expected to have greater adsorption tendencies as compared to larger particles because of the large surface areas of smaller particles allowing adsorption on the surface.

3. The optimum $\mathrm{pH}$ range can be between 5 and 7 for maximum adsorption of lead using orange peels. The minimum adsorption can be expected to occur at a $\mathrm{pH}$ of 3 because of its acidic nature. As the $\mathrm{pH}$ value increases, the adsorption capacity is also increased till a $\mathrm{pH}$ of 7 and it may remain stable in case of a further increase in $\mathrm{pH}$.

From the above study it can be concluded that instead of using harmful chemicals for the removal of heavy metals 


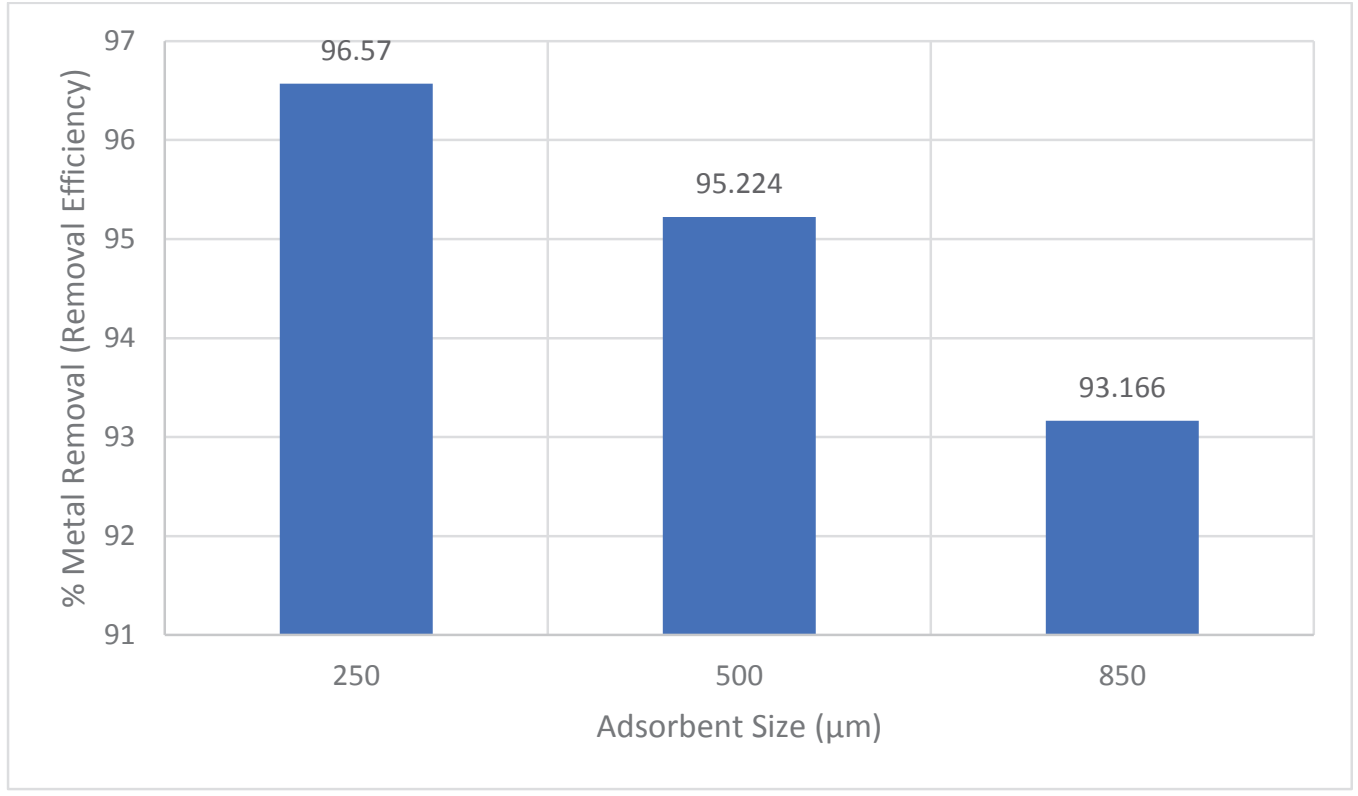

Fig. 4: Effect of adsorbent size at stock solution concentration of $15 \mathrm{ppm}$ at $\mathrm{pH} 7$ and adsorbent dose of $0.5 \mathrm{~g}$.

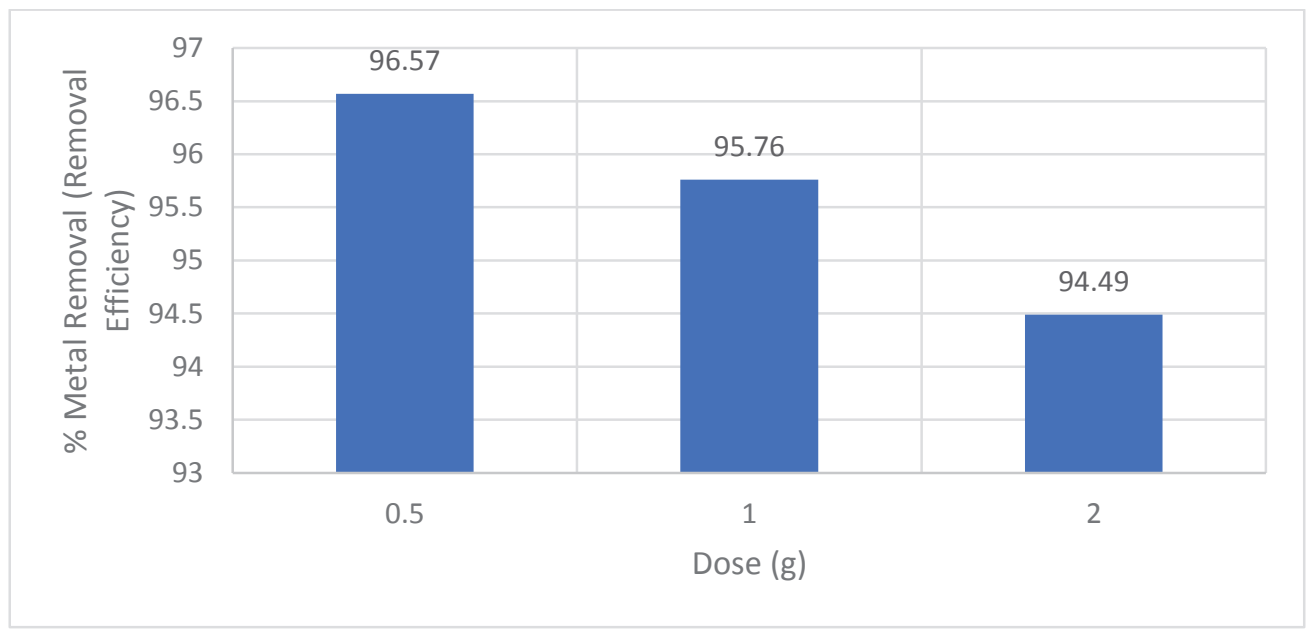

Fig. 5: Effect of adsorbent dose at adsorbent size-250 $\mu$ and pH-7 on metal removal efficiency at 15 ppm concentration.

from water, organic wastes such as orange peels, banana peels and rice husk can be used for the same. Detailed analysis of experimental data has been carried out for maximum adsorption capacity. It was found that maximum adsorption efficiency is at $\mathrm{pH} 7$.

\section{REFERENCES}

Al-Qahtani, K. M. 2016. Water purification using different waste fruit cortexes for the removal of heavy metals. Journal of Taibah University for Science, 10(5): 700-708.
Altundoğan, H.S., Altundoğan, S., Tümen, F. and Bildik, M. 2000. Arsenic removal from aqueous solutions by adsorption on red mud. Waste Management, 20(8): 761-767.

Annadurai, G., Juang, R. and Lee, D. 2003. Adsorption of heavy metals from water using banana and orange peels. Water Science and Technology, 47(1): 185-190.

Anwar, J., Shafique, U., Salman, M., Dar, A. and Anwar, S. 2010. Removal of $\mathrm{Pb}$ (II) and $\mathrm{Cd}$ (II) from water by adsorption on peels of banana. Bioresource Technology, 101(6): 1752-1755.

Barlow, M. and Clarke, T. 2017. Blue Gold: The Battle Against Corporate Theft Of The World's Water. Routledge.

Congress, U. S. 1995. Office of Technology Assessment. Adolescent Health 1. 
Czech, B., Krausman, P.R. and Devers, P.K. 2000. Economic associations among causes of species endangerment in the United States: associations among causes of species endangerment in the United States reflect the integration of economic sectors, supporting the theory and evidence that economic growth proceeds at the competitive exclusion of nonhuman species in the aggregate. BioScience, 50(7): 593-601.

Demirbas, A. 2005. Potential applications of renewable energy sources, biomass combustion problems in boiler power systems and combustion related environmental issues. Progress in Energy and Combustion Science, 31(2): 171-192.

Dobaradaran, S., Nabipour, I., Saeedi, R., Ostovar, A., Khorsand, M., Khajeahmadi, N., Hayati, R. and Keshtkar, M. 2017. Association of metals (Cd, Fe, As, Ni, $\mathrm{Cu}, \mathrm{Zn}$ and $\mathrm{Mn}$ ) with cigarette butts in northern part of the Persian Gulf. Tobacco Control, 26(4): 461-463.

Feldman, M., Cryer, B., McArthur, K.E., Huet, B.A. and Lee, E. 1996. Effects of aging and gastritis on gastric acid and pepsin secretion in humans: a prospective study. Gastroenterology, 110(4): 1043-1052.

Hegazi, H. A. 2013. Removal of heavy metals from wastewater using agricultural and industrial wastes as adsorbents. HBRC Journal, 9(3): 276-282.

Hossain, M., Ngo, H., Guo, W., Nghiem, L., Hai, F., Vigneswaran, S. and Nguyen, T. 2014. Competitive adsorption of metals on cabbage waste from multi-metal solutions. Bioresource Technology, 160: 79-88.

Hossain, M.A., Ngo, H. H., Guo, W., Zhang, J. and Liang, S. 2014. A laboratory study using maple leaves as a biosorbent for lead removal from aqueous solutions. Water Quality Research Journal, 49(3): 195-209.

Howard, G., Bartram, J., Water, S. and Organization, W.H. 2003. Domestic Water Quantity. Service Level and Health.

Khyade, V. B. and Swaminathan, M. S. 2016. Water: The pacemaker for life of earth. World Scientific News, 44: 93-125.

Le, C., Zha, Y., Li, Y., Sun, D., Lu, H. and Yin, B. 2010. Eutrophication of lake waters in China: Cost, causes, and control. Environmental Management, 45(4): 662-668.
Li, X., Qi, J., Jiang, R. and Li, J. 2016. Adsorptive removal of As (III) from aqueous solution by waste litchi pericarps. Water Science and Technology, 74(9): 2135-2144.

Lindstrom, B.R. 2012. America's Water Future and Deep Energy. Army War Coll Carlisle Barracks Pa.

Matilainen, A., Vepsäläinen, M. and Sillanpää, M. 2010. Natural organic matter removal by coagulation during drinking water treatment: A review. Advances in Colloid and Interface Science, 159(2): 189-197.

Mulligan, C., Yong, R. and Gibbs, B. 2001. Remediation technologies for metal-contaminated soils and groundwater: an evaluation. Engineering Geology, 60(1-4): 193-207.

Niemczynowicz, J. 1999. Urban hydrology and water management-Present and future challenges. Urban Water, 1(1): 1-14.

Pehlivan, E., Yanık, B., Ahmetli, G. and Pehlivan, M. 2008. Equilibrium isotherm studies for the uptake of cadmium and lead ions onto sugar beet pulp. Bioresource Technology, 99(9): 3520-3527.

Shiklomanov, I.A. 1991. The World's Water Resources: A New Appraisal and Assessmentfor the 21st century. A summary of the monograph World Water Resources prepared in the framework of the International Hydrological Programme, UNESCO.

Shukla, A., Zhang, Y.H., Dubey, P., Margrave, J. and Shukla, S. S. 2002. The role of sawdust in the removal of unwanted materials from water. Journal of Hazardous Materials, 95(1-2): 137-152.

Tarver, T. 2008. Just add water: Regulating and protecting the most common ingredient. Journal of Food Science, 73(1): R1-R13.

Tokalioğlu, Ş., Kartal, Ş. and Elci, L. 2000. Determination of heavy metals and their speciation in lake sediments by flame atomic absorption spectrometry after a four-stage sequential extraction procedure. Analytica Chimica Acta, 413(1-2): 33-40.

Vitousek, P. M., Mooney, H. A., Lubchenco, J. and Melillo, J. M. 1997. Human domination of earth's ecosystems. Science, 277(5325): 494-499. 